\section{ARTISTS OF POLTAVA REGION: MEMORIES OF IVAN ORLOV AND SERHII BESEDIN ABOUT SOLOMON ROSENBAUM}

\author{
Oksana Storchai, \\ https://orcid.org/0000-0003-0461-2816 \\ $\mathrm{PhD}$ in Art, Researcher \\ of the Department of Fine Arts and Crafts \\ of the M.T. Rylsky Institute \\ of Art Criticism, \\ Folklore and Ethnology Under \\ the National Academy of Science \\ of Ukraine, \\ Restorer of Graphic Art, \\ Kyiv, Ukraine \\ storchai_ov@ukr.net
}

\section{ХУДОЖНИКИ ПОЛТАВЩИНИ: СПОГАДИ ІВАНА ОРЛОВА I СЕРГІЯ БЕСЄДІНА ПРО СОЛОМОНА РОЗЕНБАУМА}

\author{
Сторчай Оксана Вікторівна, \\ https://orcid.org/0000-0003-0461-2816 \\ кандидат мистецтвознавства, \\ науковий співробітник відділу \\ образотворчого та декоративно- \\ прикладного мистецтва, \\ Інститут мистецтвознавства, \\ фольклористики та етнології \\ ім. М. Т. Рильського НАН України, \\ художник-реставратор творів графріки, \\ Київ, Україна \\ storchai_ov@ukr.net
}

Abstract

The purpose of the study. In Ukrainian art criticism, so far one can find information about many talented artists only in encyclopedic articles, reference books and short references in general works on the history of national art. The same situation is with the study of heritage of creative artist Solomon Aronovich Rosenbaum (1885-1941). Definitely, the article, which is devoted to the publication of archival material about the artist's creative biography with an introductory article and commentary is relevant and has scientific value. Research methods. The researcher used the methods of historical and art analysis and empirical knowledge. Scientific novelty. For the first time, valuableand important archival materials from creative biography of Solomon Rosenbaum are introduced into scientific parlance. Summary. The archival materials published are memories of artists I. Orlov and S. Besedin about Solomon Rosenbaum and sections of encyclopedic article of Z. Lashkun. The preface and commentary to them would be a good basis for further research of the master's work and for preparing a monograph and establishing a catalog of his works.

\section{Анотація}

Мета дослідження. В українському мистецтвознавстві дотепер про багатьох талановитих художників у наявності є тільки енциклопедичні статті у довідковій літературі та короткі згадування у загальних працях з історії вітчизняного мистецтва. Такий стан вивченості творчості стосується і самобутнього живописця Соломона Ароновича Розенбаума (1885-1941). Безумовно, стаття, яка присвячена публікації архівного матеріалу з творчого життєпису мистця зі вступною статтею і коментарем, на часі та має наукову цінність. Методи дослідження. Використано методи історичного і мистецтвознавчого аналізу, метод емпіричного пізнання. Наукова новизна. Вперше до наукового обігу вводиться цінний і вагомий архівний матеріал з творчої біографії С. Розенбаума. Висновки. Опублікований архівний матеріал - спогади художників І. Орлова і С. Бесєдіна про С. Розенбаума, розділи енциклопедичної статті 3. Лашкул, передмова і коментар до них буде гарним підґрунтям для подальшого дослідження творчості майстра та написання монографічної статті й складання каталогу його творів.

Key words:

Solomon Rosenbaum (1885-1941), I. Orlov, S. Besedin, Z. Lashkun, memories.

\section{Ключові слова:}

Соломон Аронович Розенбаум (1885-1941), І. Орлов, С. Бесєдін, 3. Лашкул, спогади. 
Вступ 11 «Настоящий художник! Певец Полтавщины! просто, без формалистического кривляния. Поэтично. Как звучит цвет! Как легко написано! Но никто не знает, как это трудно. Артист!..» так про талановитого українського пейзажиста Соломона Ароновича Розенбаума казав «сонячний Бурачек»" (Беседин, 1971) (Рис. 1.1). Зазначимо, що до С. Розенбаума неможливо застосувати визначення «провінційний художник». Він справді набагато масштабніший і може презентувати український пейзаж першої половини XX століття у світовому мистецтві саме у реалістичному напрямі. Його живописні пейзажі високого художнього рівня зі своєю неповторною витонченою манерою виконання, тонкою ліричністю, психологічністю, вишуканою тональністю, декоративністю і бездоганним смаком мають повну і самодостатню цінність.

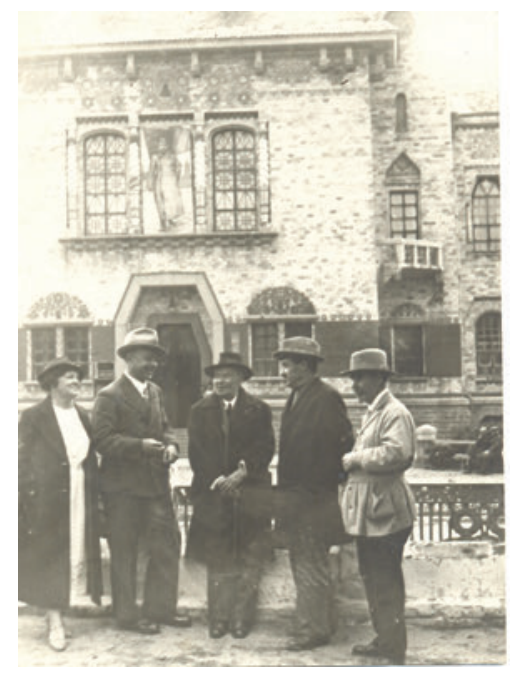

Рис. 1.1. М. Бурачек з художниками м. Полтави. Фото. Червень 1941 р.

Зліва направо: Дружина М. Бурачека - О. Бурачек, П. Горобець, М. Бурачек, С. Розенбаум, М. Донцов.

Fig. 1.7. M. Burachek with artists of Poltava. Photo. June 1941.

From left to right: Wife of M. Burachek - O. Burachek, P. Gorobets, M. Burachek, S. Rozenbaum, M. Dontsov.

Творів С. Розенбаума збереглося мало, та й публікацій, присвячених дослідженню його творчості, теж замало. Пояснюється це трагічністю долі його малярської і графічної спадщини, більшість якої загинула під час Другої Світової війни. Жахлива доля спіткала і самого мистця - його спалили фашисти в 1941 році. 3 листа дружини Людмили Миронівни Розенбаум дізнаємося, що «Все лучшие его работы были в начале Отечественной войны взяты Полтавским Музеем для эвакуации, но, к несчастью, они не были эвакуированы и сгорели вместе с музеем» (Розенбаум Соломон Аронович, б. р.). Зараз поодинокі твори мистця зберігаються в музеях Києва², Полтави та Дніпра.

\footnotetext{
${ }^{1}$ Микола Григорович Бурачек (1871 - 1942) - український живописець, письменник, мистецтвознавець, сценограф, актор, викладач.

${ }^{2}$ Висловлюю щиру подяку провідному науковому співробітнику Національного музею «Київська картинна галерея» Н. Агєєвій і співробітнику Національного художнього музею України О. Кравчук та доценту НАОМА В. Петрашику у підготовці ілюстративного матеріалу.
} 
На нашу думку, будь-яка інформація, що стосується творчого життєпису художника, є цінною і вагомою, а тому підготовлено для публікації цікавий архівний матеріал - «Воспоминания о Художнике Соломоне Ароновиче Розенбауме» живописця Івана Івановича Орлова (1875-1950) (Орлов, б. г.) та «Художник света и тепла» стаття - спогад (звісно, з притаманною для того часу радянською риторикою) Сергія Фотієвича Бесєдіна (1901-1996)1 (Беседин, 1971). Було також винесено в Додаток важливий фактичний матеріал - розділи «участь у виставках, роботи в музеях, бібліографія та репродукції» з архівної енциклопедичної статті 3. Лашкул (Розенбаум Соломон Аронович, б. р.; Додаток). Інформація, яка міститься у цих пунктах, має непересічне значення для подальшого дослідження творчості художника. Так, наприклад, твори, що зазначені у розділі «участь у виставках», фактично є найповнішим списком усієї образотворчої спадщини майстра на сьогодні. Це дасть можливість продовжити пошук живописних і графічних робіт майстра, які могли б зберегтися в музейних та приватних збірках, а також - світлин з тих, що не збереглися, репродукцій в друкованих джерелах, - з метою укладення каталогу творчої спадщини художника. І. Орлов у спогадах зазначає: «Возможно, что его этюды еще где-то сохранились. Эти те этюды где он изображал Днепр в местах запорожской сечи перед затоплением Днепра - плотиной Днепровской Электростанцией. Он был приглашен туда вместе с другими Худож. Украины» (Орлов, б. г.).

Звісно, не менш корисними будуть й інші розділи - «роботи в музеях, бібліографія та репродукції» для написання монографічної статті, присвяченої С. Розенбауму.

\section{Методологія та аналіз джерельної бази}

\section{Результати дослідження}

Як зазначалося вище, бібліографія творчості художника дуже скромна - короткі енциклопедичні статті в довідковій літературі, тому автором було зібрано важливий архівний матеріал, що вперше вводиться до наукового обігу.

У статті ми розглянемо цікаву інформацією з творчого життєпису художника. Соломон Аронович Розенбаум народився 29 грудня 1885 р. в Полтаві у родині крамаря (Рис. 4.1).

Дата народження в електронних ресурсах і, наприклад, у довіднику «Митці України», інша - 19 (31) грудня (Кудрицький, 1992, с. 497-498). В анкеті, заповненій вдовою художника, зазначається 29 грудня (Розенбаум Соломон Аронович, б. р.), дата, до якої ми більше схиляємося, а загалом це питання залишається відкритим для наступних досліджень. Ще належить знайти метричні записи в архівах м. Полтави, щоб зрозуміти розбіжності з датою народження митця в різних джерелах.

\footnotetext{
${ }^{1}$ Сергій Фотієвич Бесєдін (1901 - 1996) - живописець, графік, майстер портрету, педагог.
} 


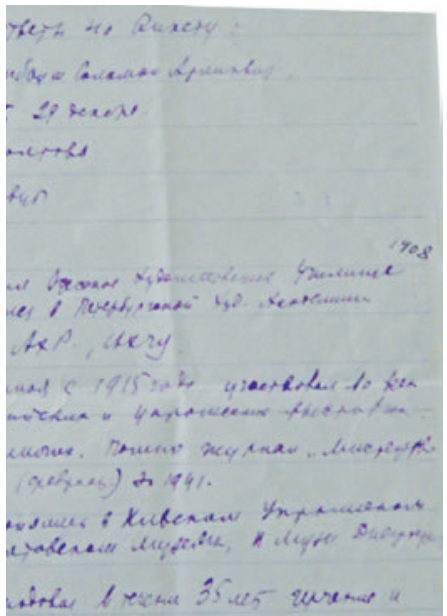

Рис. 4. 1. Відповіді на анкету Людмили Розенбаум. Фото. Архів ІМФЕ ім. М. Т. Рильського НАН України.

Fig 4.1. Answers to the questionnaire of Lyudmila Rosenbaum. Photo. Archive of the M. T. Rylsky Institute of art criticism, folklore and ethnology under the National Academy of Science of Ukraine.

Фахову освіту С. Розенбаум отримав в Одеському художньому училищі (1901 - 1908), де його викладачем був славнозвісний К. Костанді. В електронних ресурсах, архівному матеріалі анкеті, написаною вдовою художника, довіднику «Митці України» вказується на той факт, що мистець продовжив свою освіту в Санкт-Петербурзький Академії мистецтв (Кудрицький, 1992). Свідчення про його навчання в С.Пб АМ не знайшло документального підтвердження, так в «Юбилейном справочнике Императорской Академии художеств. 1764 - 1914» С. Кондакова (1914) С. Розенбаум не значиться. Напевно, він міг навчатися приватно в майстерні когось із професорів Академії (в електронних ресурсах - в 1908 р., 1910-1912рр.), але офіційно не був прийнятий до неї. Саме таким чином можна пояснити ці розбіжності.

В інших джерелах про навчання художника в С.Пб АМ не зазначається, а саме у статті «Художник света и тепла (памяти Соломона Розенбаума)» М. Спарбер пише: «Не осуществилась и его мечта учиться в Петербургской Академии искусств - снова мешает пресловутая процентная норма для евреев» (Спарбер, 2001). Крім того, як відомо в 2011-2012 рр. у Національному художньому музеї України була виставка «Іван Мясоєдов та його доба». В каталозі виставки в біографічній довідці про С. Розенбаума зазначається, що він навчався в Одеському художньому училищі (1901-1908) у К. К. Костанді та у майстерні І. Г. Мясоєдова в Полтаві (1915-1917) (Курчакова, \& Бочарова, 2012, с. 34) і тільки. Цікаво, як про навчання у І. Мясоєдова пише М. Спарбер: «Важным событием в его жизни была работа в мастерской Ивана Мясоедова, где он почти ежедневно встречался с его отцом - Григорием Григорьевичем Мясоедовым - основателем Товарищества художников -передвижников. Розенбаум пишет картину «Полтавская дача Мясоедова», исполненную

1 Іван Григорович М'ясоєдов (псевд. Євген Зотов; Mjasoedov, Iwan. alias Zotow, Eugene; 1881 - 1953) - український живописець, графік, викладач. 
Деміург: ідеї, технології, перспективи дизайну № 2 (2018) Demiurge: ideas, technologies, perspectives of design № 2 (2018)

с большой любовью к учителю и впоследствии удостоенную Серебряной медали. Судьба этой картины необычна: она была куплена любителем на Петербургской весенней выставке в 1916 году, и вот до сего времени сохраняется в художественном музее Полтавской средней школы № 6» (Спарбер, 2001). у цілому, період навчання з фаху завжди є важливим в творчій біографії кожного художника. Це час становлення творчої індивідуальності, значного впливу викладачів і кумирів мистецького світу, формування світогляду, пошуку свого стилю, місця тощо.

Починаючи з 1915 року, С. Розенбаум бере активну участь у художніх виставках, але основна його творча діяльність припадає на радянський час. 1926 року він демонструє свої твори на виставці картин Полтавської філії АХPР'a ${ }^{1}$ (Рис. 4.2), а з 1927 р. і до 1941 р. стає постійним експонентом АХЧУ², обласних та республіканських виставок.

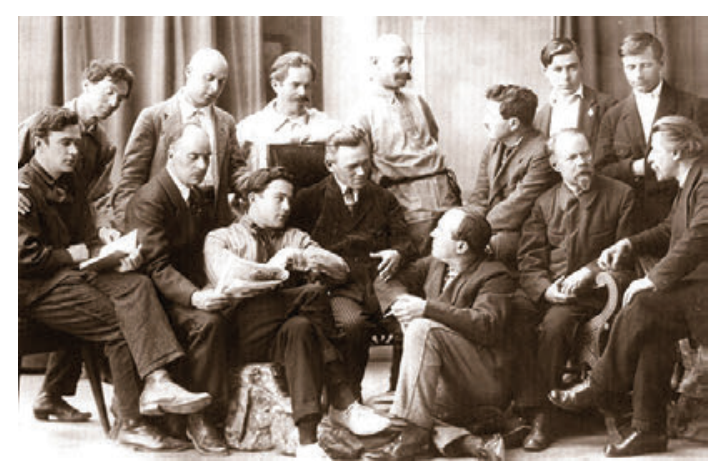

Рис. 4.2. Художники - члени Полтавської філії АХРР. Фото. 1926.

Зліва направо: верхній ряд - М. Брукман, Л. Векштейн, М. Донцов, В. Магденко,

С. Розенбаум, двоє невідомих: нижній ряд: Д. Ангельський, І. Орлов, П. Горобець, троє невідомих, А. Федоренко. (55 - АХРР).

Fig. 4.2. Artists - members of the Poltava branch of the Aassociation of revolutionary artists of Russia. Photo. 1926. From left to right: the upper row - M. Brookman, L. Vekshtein, M. Dontsov, V. Magdenko, S. Rosenbaum, two unknown men: lower row: D. Angelski, I. Orlov, P. Gorobets, three unknownmen, A. Fedorenko.

Він був головою Полтавського Обласного Правління СРХУ та провадив активну мистецько-громадську діяльність. Загалом, у Полтаві на той час існував потужний художній осередок, який склали високопрофесійні і талановиті живописці, графіки зокрема, Д. Ангельський, С. Бесєдін, М. Бокий-Бикадиров, М. Брукман (написав портрет С. Розенбаума), І. Дряпаченко, М. Донцов, П. Горобець (Рис. 4.3), В. Магденко, І. Орлов, учень С. Розенбаума - В. Павлюченко, С. Розенбаум, А. Федоренко, Г. Цисс та інші.

Судячи з їхньої творчості, більшість майстрів була спілкою однодумців у питаннях мистецтва і його розуміння, вони продовжували кращі традиції реалістичного живопису попередніх

\footnotetext{
${ }^{1}$ Асоціація художників революційної Росії (з 1928 року - Асоціація художників революції, АХР) існувало з 1922 по 1932 рр.

${ }^{2}$ Асоціація художників червоної України (АХЧУ) - творче об'єднання українських радянських художників. Ініціат. група АХЧУ виникла 1923 у Києві, а статут офіцій-но затверджено у серпні 1926. Схвалювала відому декларацію Асоц. художників рев. Росії (АРМУ) від 1922. 1929 київ. група членів вийшла зі складу АХЧУ й засн. Укр. мист. об'єднання. 1930 АХЧУ перетворилася на Всеукраїнську асоціацію пролетарських митців. АХЧУ мала власне вид-во з плакат. майстернею при ньому (1929-32), матеріали якого успадкувало вид-во «Мистецтво».
} 


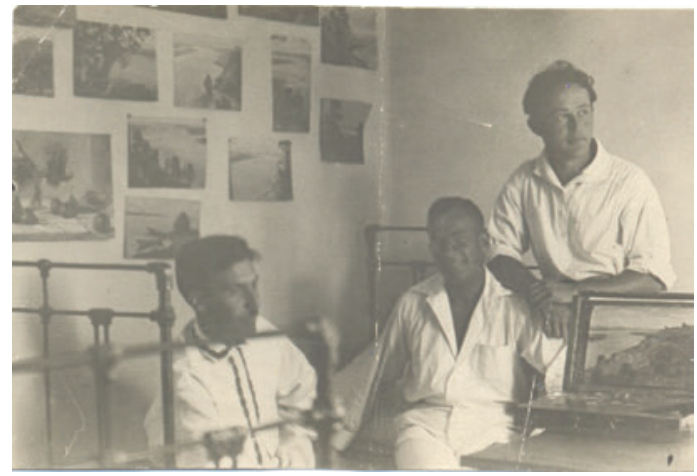

Рис. 4.3. У майстерні П. Горобця.

Фото. 1930-тірр. м. Полтава.

Зліва направо: М. Донцов, С. Розенбаум, П. Горобець.

Fig. 4.3. In the studio of P. Gorobets. Photo. The 1930s. Poltava.

From left to right: $M$. Dontsov,

S. Rozenbaum, P. Gorobets.

поколінь з творчою асиміляцією новацій західноєвропейського живопису, імпресіоністичного зокрема. Художники надавали перевагу пейзажному, портретному і побутовому жанрам, писали залюбки і натюрморти. Працюючи у цих жанрах, легше було бути більш вільним, певною мірою дистанціюватися від тодішньої ідеології. Дійсно, твори цих мистців, які доступні для вивчення, свідчать майже про відсутність радянської риторики періоду сталінського режиму, репресій, але це не значить, що таких робіт немає. Зазначимо, що в творчому доробку кожного радянського художника цього періоду є картини присвячені В. Леніну, В. Сталіну та іншим вождям. Ці картини були свого роду індульгенцією для збереження свого життя і життя членів своєї родини. До слова, зараз неможливо зрозуміти, уявити, що тільки за стиль, тобто манеру виконання твору в 1930-ті роки могли розстріляти, як це сталося з бойчукістами, в яких тематика була правильною.

Провідним жанром творчості С. Розенбаума стає пейзаж, оспівування природи рідної Полтавщини. С. Бесєдін писав: «Слово «мотив» редко можно услышать сегодня среди современных художников-пейзажистов, но в 20-30-е годы оно было любимым словом художников и имело иной смысл, чем слово «этюд». / Художник на мотиве подмечает характерные особенности натуры, ее состояние. В мотивах Соломона Ароновича были не видики, а содержательные рассказы о природе. Мотивы «Дорожка», «Осенью», «Солнечно», «Ветерок», «Свежо» глубокое проникновение в смысл явления, частица большой жизненной правды, действительности, тонко и вдохновенно отображенная живописцем» (Беседин, 1971).

Роздивляючись пейзажі майстра, на думку спадає, що С. Розенбаум добре знав і любив японську кольорову ксилографію (Рис. 4.4), захоплювався іï особливою естетикою, а також і творчістю А. Маневича (Рис. 4.5).

З робіт С. Розенбаума і А. Маневича можна вибудувати окремий напрямок в українському пейзажному живописі, міському, зокрема, з характерним для цих мистців витонченим почуттям декоративізму, смаку, своєрідною художньою лексикою і світовідчуттям, пластичною мовою, ритмом, тонким ненав'яз- 
Деміург: ідеї, технології, перспективи дизайну № 2 (2018) Demiurge: ideas, technologies, perspectives of design № 2 (2018)

ливим психологізмом. Як приклад, зазначимо відомі пейзажі С. Розенбаума зі збірки Національного художнього музею України - «Зимовий день» (напевно 1930-ті роки, полотно, олія) (Рис. 4.6; 4.7),

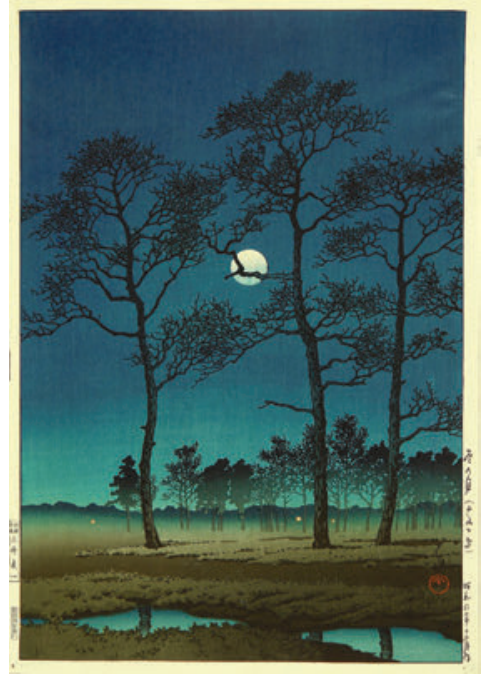

Рис. 4.4. Хасуі Кавасе (Hasui Kawase; 1883-1957). Пейзаж. Японія. Папір, кольорова ксилографія.

Fig. 4.4. Hasu Kawase (1883-1957). Landscape. Japan. Paper, color xylography.
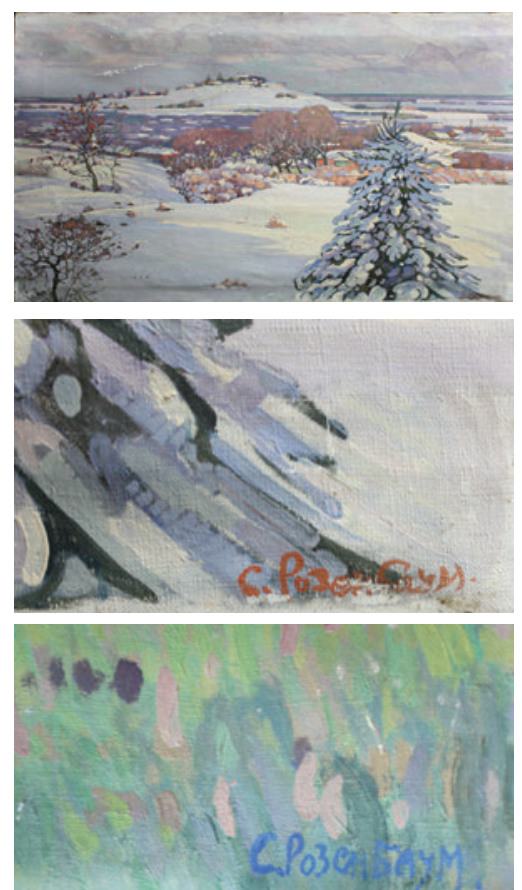

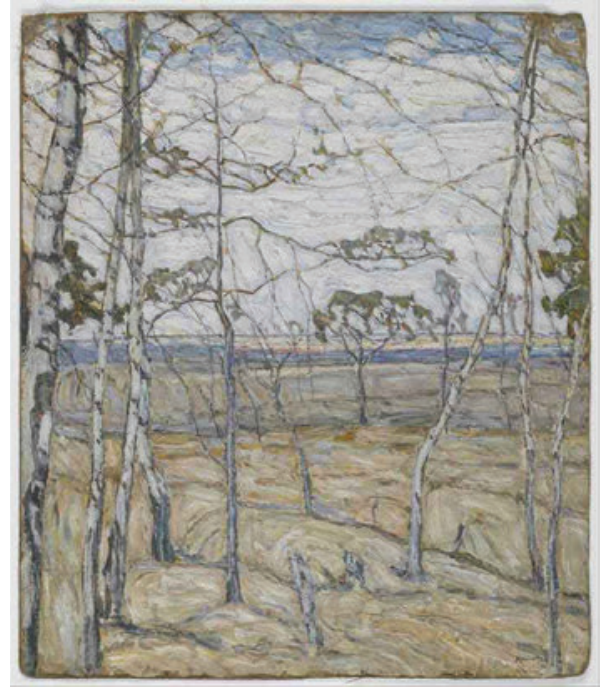

Рис. 4.5. Абрам Аншелович Маневич. Берези. 1911, полотно, олія.

Fig. 4.5. Abram Anselovich Manevich. Birch trees. 1911, oil on canvas.

Рис. 4.6. Соломон Аронович Розенбаум. Зимовий день.

1930-ті рр., полотно, олія. Національний художній музей України.

Fig 4.6. Solomon Aronovich Rosenbaum. Winter day. The 1930s, oil on canvas. National Art Museum of Ukraine.

Рис. 4.7. Підпис Соломона Ароновича Розенбаума.

Fig 4.7. Signature of Solomon Aronovich Rosenbaum. 
«Весняний пейзаж» (1937, полотно, олія) (Рис. 4.8),

Полтавського художнього музею (галерея мистецтв) ім. М. Ярошенка «Вулиця у Полтаві» (1920, полотно, олія) (Рис. 4.9).
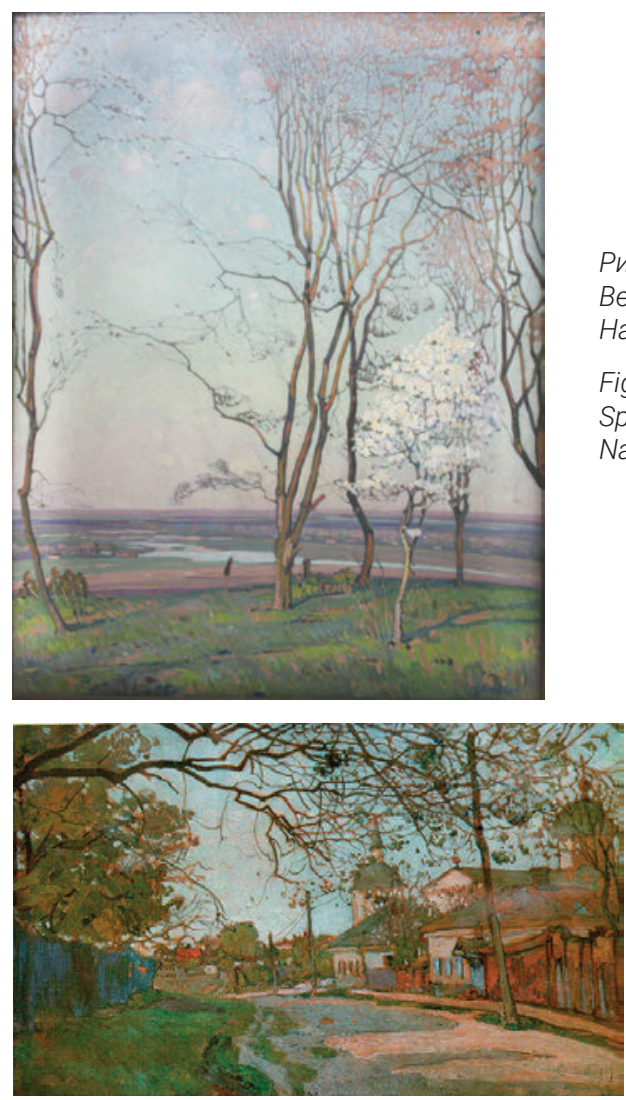

Рис. 4.8. Соломон Аронович Розенбаум. Весняний пейзаж. 1937, полотно, олія. Національний художній музей України.

Fig. 4.8. Solomon Aronovich Rosenbaum. Spring landscape. 1937, oil on canvas. National Art Museum of Ukraine.

В останні роки перед Другою Світовою війною художник пише низку індустріальних пейзажів, зокрема «Дніпрогес» і «Домни в Макіївці» тощо.

С. Розенбаум успішно працював також над портретом і натюрмортом, в монументальному малярстві. У 1928 році він виїздить з групою художників на Дніпрельстан і наслідком цієї подорожі було його перше панно «На Дніпрельстані». У 1935 році мистець разом з Ів. Орловим виїздить до Ворошиловграда (Луганськ. - О. С.). У збиральному цеху вагонобудівного заводу вони виконали багато начерків, як підготовчого матеріалу до панно «Збірка паровоза «Фелікс Дзержинський»» для ворошиловградського Будинку громадських організацій.

Поряд з творчою роботою С. Розенбаум багато працює і як педагог. Він викладав протягом 35 років рисунок і креслення в школах, художньому технікумі та будівельному інституті Полтави. Отже маємо такий короткий огляд творчого життєпису С. Розенбаума. 
Деміург: ідеї, технології, перспективи дизайну № 2 (2018)

Demiurge: ideas, technologies, perspectives of design № 2 (2018)

\begin{tabular}{r|}
\hline Наукова \\
новизна та \\
практичне \\
значення \\
дослідження \\
\hline
\end{tabular}

Орлов І. І. «Воспоминания о Худ.[ожнике] Соломоне Ароновиче Розенбауме»'.

С Соломоном Ароновичем я впервые познакомился в 1918 г. когда Полтавские Художники объединились в Союз Художника. Позднее когда в Полтаве была организована 1-я выставка Полт. Худож. я увидел его работы. Он тогда выставил небольшие этюды. Мне тогда Его работы своей манерой выписывания деталей напоминали Бродского², которого он обожал. Он любил поэтичные уголки Полтавы, особенно домики еврейской бедноты ютящейся по Новопроложенной ул. ныне ул. Шелом-Алейхема, с их немного восточным характером. Более близко я узнал Его как Художника и человека, будучи головой ИЗО при искусств. В это время часто приходилось исполнять работы по заданиям Губисполкома. С. А. Розенбаум окончил Одесскую Художественную Школу. В 1924 г. мы с ним устроили индивидуальню выставку в фоэ Полтавского театра. Выставка прошла с большим успехом. Критики хорошо отзывались о наших работах. По открытии в Полтаве филиала АХЧУ, в котором я был головою, и мне чаще пришлось встречаться с художником. С этого времени близко сошелся с Соломоном Ароновичем. Нас сближали общность взглядов и любовь к Искусству. В 1935 г. Харьковский кооператив "Художник», в котором мы состояли членами, предложил нам написать в Ворошиловграде панно, для дома общ. орган. изображающее сборки паровоза «Феликс Дзержинский». Эскиз панно сделанного мною был одобрен Харьковскими Художниками. В Ворошиловграде мы много сделали зарисовок в сборочном цеху Паровозного завода. Над панно мы проработали два месяца. За это время мы жили и все время проводили вместе, а потому хорошо узнали друг друга. Меня всегда поражала его работоспособность. Каждую вещь он доводил до конца.

Работая над этюдом с натуры, он приходил на одно и тоже место раз по пяти и несмотря на это он не подходил натуралистически к своим работам, а вкладывал свое свойственное ему понимание природы. Недостаток его был в том, что он очень нетерпимо относился к Художникам, участвовавшим с ним на выставках, не отдавая должного их работам. Для своих картин он никогда не делал эскизов, а писал так как видел. Большое влияние на него оказали работы Мясоедова Ивана Григорьевича, сына старого передвижника. С. Мясоедовым он был долгое время в близких товарищеских отношениях. Ужасная смерть прервала его творческий путь в самом расцвете. Он был певцом Украинской природы в частности Полтавщины. Из его работ мало что сохранилось. Не смотря на все старания удалось Полтавскому музею приобрести несколько этюдов и то не из лучших. Все остальные его работы погибли.

\footnotetext{
${ }^{1}$ В одному з листів вказується рік написання спогадів «Художник І. І. Орлов 26 травня 1948 р. надіслав нам «Воспоминания о худ. Соломоне Ароновиче Розенбауме». На конверті написи: «Киев. / Институт Искусств / Владимирская 55 / Зав. відділом образотворчого мистецтва / Б. С. Бутник - Сіверському / Кременчуг, ул. Равенко № 1 / Орлов Ив. И.». Розенбаум Соломон Аронович (папка) / підготовчі матеріали до неопублікованого словника «Художники Радянської України» (автори: Б. Бутник-Сіверський, З. Лашкул, В. Ткаченко, технічний секретар Т. Радзієвська. Кінець 1940-х - 1950-ті рр.). - Архів відділу образотворчого та декоративно - прикладного мистецтва ІМФЕ ім. М. Т. Рильського НАН України. Нумерація аркушів відсутня. Спогади публікуються зі збереженням авторської стилістики і орфографії з незначними редакторськими правками.

${ }^{2}$ Ісак Ізраїльович Бродський (1884 - 1939) - український та російський живописець, графік.
} 
Если Вас интересует его фото, хотя и не достаточно хорошее, Вы можете его достать в Союзе Совет. Худ. Украины. Там в моих делах и сведениях о работе, есть большой снимок, где мы с ним работаем в Ворошиловграде, над панно - Сборка паровоза «Феликс Дзержинский». Возможно, что его этюды еще где-то сохранились. Эти те этюды где он изображал Днепр в местах запорожской сечи перед затоплением Днепра - плотиной Днепровской Электростанцией. Он был приглашен туда вместе с другими Худож. Украины. Вот все что я могу сказать о С. А. Розенбауме.

Ваш И. Орлов

\section{Сергій Бесєдін «Художник света и тепла С. А. Розенбаум» ${ }^{\text {. }}$}

В начале 30-х годов я впервые познакомился с творчеством Соломона Ароновича Розенбаума, хотя имя его сльшал: оно часто упоминалось в среде художественной общественности. О С. А. Розенбауме говорили с уважением, и чувствовалось, что говорят о художнике самобытного, исключительного дарования. Критика также благосклонно уделяла ему внимание.

В залах здания Наркомпроса в Харькове, по улице Артема (тогда столица УССР находилась в Харькове), была размещена большая выставка художников Советской Украины (ныне в этом здании педагогический институт им. Г. С. Сковороды). На ней среди многочисленных художественных произведений были и работы Соломона Ароновича.

Его полотно «Полтавские дали» привлекало общее внимание, выделяясь своим оригинальным композиционным построением, лирической мягкостью, звонкостью колорита. Около него всегда стояли и маститые мастера искусства, и буйно дерзающие молодые художники, и многочисленные зрители. Каждый находил в нем мысли, чувства, созвучные своим.

На полотне - залитые солнцем безбрежные дали чарующих полтавских просторов. Золотятся песчаные россыпи берегов Ворсклы, между деревьями змейками вьются розовато-пепельные тропинки, а на горизонте силуэтятся бархатным сине-оливковым массивом леса.

Поэтичность природы передана сочным пастозным письмом, затейливым ажурным рисунком, а свет, заливающий природу, светился в цвете, тонко почувствованном художником. Правда жизни, ее живое дыхание, красота и величие природы, воссозданные реалистическим языком художника, захватывали и восхищали.

К картине мягко подошел среднего роста, плотный, с удивительно добродушной улыбкой человек. Стоявшие вежливо посторонились, притихли, глаза многих устремились на него.

«Бурачек, - шептали присутствующие, - Николай Григорьевич Бурачек, солнечный Бурачек...» Так называли одного из талантливейших художников украинского пейзажа.

С радостным удивлением (он всегда светился радостью), искрящимися глазами смотрел он на пейзаж

- Розенбаум! - восторженно воскликнул он. - Настоящий художник!

Певец Полтавщины! Просто, без формалистического кривляния.

Поэтично. Как звучит цвет! Как легко написано! Но никто не знает, как это трудно. Артист!..

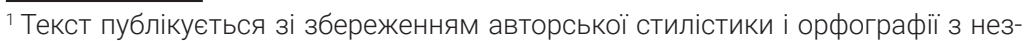
начними редакторськими правками.
} 
Деміург: ідеї, технології, перспективи дизайну № 2 (2018)

Demiurge: ideas, technologies, perspectives of design № 2 (2018)

Все мы внимательно слушали большого мастера, его лестный отзыв о товарище по работе. От картины веяло живой правдой жизни.

Цвет - душа большого искусства - светился с полотна, как на творениях талантливого мага, волшебника живописи А. И. Куинджи, который мастерски владел тайнами палитры, о котором создано и столько создается легенд.

Полтавчанин С. А. Розенбаум безусловно знал творчество Куинджи как и творчество замечательного пейзажиста А. Маневича, но шел своей дорогой, имел свой, ярко выраженный индивидуальный почерк.

Он пел своим голосом, свою песню и, как подобает настоящему художнику, имел свою тему, о которой рассказывал задушевно, тепло, сердечно. И что самое главное - он пел песню так, как чувствовал, - реалистично и искренне. А ведь это были 30-е годы - годы напряженной борьбы честных художников с антиреалистами, рьяно усложнявшими вопрос восприятия художником действительности разными хитростями, предававшими анафеме реализм, хоронившими «старушку» - станковую живопись.

Но в большом искусстве все так, как и в жизни, и простота - признак подлинного таланта.

$\star \star \star ~$

Спустя некоторое время, будучи в Полтаве, я лично познакомился с Соломоном Ароновичем на одном из заседаний ученого совета Полтавского историко-краеведческого музея. Я увидел худощавого, среднего роста, внешне ничем не выдающегося человека; только озаренные глубоким внутренним светом глаза говорили о духовном богатстве и напряженной интеллектуальной жизни этого милейшего товарища.

Скромность и застенчивость, как я узнал позже, были его характерными чертами. Приветливый, добродушный, всегда молодой душой, он везде и во всем был художником.

Среди полтавских художников он пользовался заслуженным признанием и был главой их небольшой корпорации того времени.

Он дышал искусством, живопись была делом его жизни, верность реалистическим принципам изобразительного искусства он свято носил в своем отзывчивом, любвеобильном сердце.

Тонко, остро чувствовал и видел жизнь, любил ее и умел отображать ее в своих задушевных мотивах.

В произведениях С. А. Розенбаума природа, жизнь согреты теплотой его сердца. В них столько интимного чувства и любви.

Художник знал тайны живописного мастерства, знал тонкости смешения красок, но никогда не подменял ими реального богатства натуры. Человек большой культуры, Соломон Аронович щедро отдавал свои обширные знания, свои незаурядные способности художника всем, кто с ним общался. Он долгие годы преподавал живопись и рисунок в полтавских школах. Многие уже ставшие сегодня художниками с любовью и признательностью вспоминают его как своего первого учителя, с гордостью говорят о нем как о педагоге, которого ученики помнят всю жизнь.

Как-то серебристым осенним днем мы встретились в его небольшой уютной комнате. Она была приемной, музеем и рабочей мастерской художника. Когда я зашел, Соломон Аронович писал из окна комнаты этюд так хорошо знакомой ему улицы Полтавы. Домики, забор, деревья, слегка тронутые синевой вечера, дышали осенней прохладой. 
Уверенная кладка мазка сочно лепила деревянный забор, неровную землю улицы и сквозь ажур деревьев свинцово-малиновое вечернее небо.

Художник не терял [ни] минуты и, непринужденно ведя беседу со мной, продолжал писать этюд.

«Уж очень люблю жемчужный цвет осени! - как бы оправдываясь, говорил художник и, широко поводя рукой в пространстве, прибавил: А это мои мотивы, мои песни»...

Стены комнаты были увешаны его работами. В особых багетах висели картины других художников - его небольшая личная коллекция.

Комната его - сама Полтавщина со всей ее пышной, богатой природой, чарующей красотой, которую знал, любил и так проникновенно писал художник в своих неповторимо прекрасных мотивах.

Природа на его картинах и этюдах улыбалась и грустила, бурно резвилась, играя с ветром, и нежно мечтала в переливах, тонко подмеченных и переданных художником цветовых нюансов. Сумма работ говорила о неутомимом трудолюбии художника.

Слово «мотив» редко можно услышать сегодня среди современных художников-пейзажистов, но в 20-30-е годы оно было любимым словом художников и имело иной смысл, чем слово «этюд».

Художник на мотиве подмечает характерные особенности натуры, ее состояние. В мотивах Соломона Ароновича были не видики, а содержательные рассказы о природе. Мотивы «Дорожка», «Осенью», «Солнечно», «Ветерок», «Свежо» - глубокое проникновение в смысл явления, частица большой жизненной правды, действительности, тонко и вдохновенно отображенная живописцем.

Простой мотив «Дорожка», а сколько в нем глубокой мысли, души художника. Освещенная солнцем полянка. От деревьев падают тени.

И вьется дорожка в даль полтавских просторов. Дорожка манит, зовет идти по нехоженым тропам. Цвет и форма подчинены замыслу, они предметны и осязаемы.

«Есть места природы... напишешь один раз и как бы сказал все.

Как и в общении с людьми: поговорил - и человек весь как на ладони. Но есть такие места, такая природа, такая глубина, такое пластическое разнообразие, что пишешь и не напишешься. Вот такая полтавская земля. Пишу уже сколько лет, и каждая встреча новая.

«Пишу, как горький пьяница, - запоем», - застенчиво, сердечно говорил С. А. Розенбаум, и я, как сегодня, слышу его мягкий, задушевный говорок, вижу его непередаваемую сердечную улыбку светящихся глаз.

Увлеченно рассказывал Соломон Аронович о тонкостях профессии художника. Расстались мы далеко за полночь. Была тихая ночь, теплое рукопожатие... и больше я не видел художника света и тепла, труженика искусства, доброго, сердечного С. А. Розенбаума.

После Великой Отечественной войны узнал, что в дни испытаний Соломон Аронович не мог оставить свои мотивы, свои песни, своих детей одних, остался с ними и погиб вместе с ними. Погиб, как и жил, художником большого доброго сердца.

Художник профессор Сергей Фотиевич Беседин. 
3 архівної енциклопедичної статті 3. Лашкул «Розенбаум Соломон Аронович». (Розенбаум Соломон Аронович (папка) / підготовчі матеріали до неопублікованого словника «Художники Радянської України» (автори: Б. Бутник-Сіверський, 3. Лашкул, В. Ткаченко, технічний секретар Т. Радзієвська. Кінець 1940-х - 1950-ті рр.). - Архів відділу образотворчого та декоративно - прикладного мистецтва ІМФЕ ім. М. Т. Рильського НАН України. Нумерація аркушів відсутня): «Участь у виставках: 1926. Виставка картин Полтавської філії АХРР’а. Полтава: 1. Березняк; 2. Будяк; 3.Верби; 4. Весняний день; 5. Вестибюль. Карт. Галереї Полтавського Держ. музея; 6. Вечір; 7. Вечір. Панно; 8. Вияснюється; 9. Ворскло (заводь); 10-12. Вуличка; 13. Голуб'ятня; 14. День кінчається; 15. Дитяча лікарня; 16. За плугом; 17. Зима; 18. Зимовий захід; 19. Кімната старих майстрів у Карт. Гал. Полт. Держ. Музея; 20.Кузні; 21. Кулики; 22. Ленінці за роботою (4 трудшкола); 23. Літній день; 24. Млин; 25. Молоді осички; 26. На заході; 27-28. Надвечір; 29. Натюрморт; 30. Околиці; 31-32. Околиці Полтави; 33. Осики; 34. Осінній день; 35. Останні осінні дні; 36. Пам'ятник 18 сторіччя; 37. Перший сніг; 38. Полудень; 39. Портрет вантажника; 40. Портрет М.В.; 41. Портрет ткалі Оляни П.; 42. Портрет худ. Брукмана (герой праці). Малюнок; 43. Похмурий день; 44-46. Пролетарські кутки; 47. Селянський двір; 48. Сірий день; 49. Соняшний день; 50. Ставок; 51. Тополева алея; 52. Хата. - 1927. Перша всеукраїнська виставка художників Червоної України. Харків: 53. Ввечері. Олія; 54. Вулиця м.Полтави. Олія; 55. Вулиця на селі Жуки. Олія; 56. Дитяча лікарня. Олія; 57. До весни. Олія; 58. Залізничне сельце. Олія; 59. Залізничне сельце м. Полтави. Олія; 60. Захід. Олія; 61. Захід сонця. Олія; 62. Зима. Олія; 63. Кімната старих майстрів. Олія; 64. Кузня. Олія; 65. Лінійки. Олія; 66. На вигоні. Олія; 67. Натюрморт. Соняшники. Олія; 68. Осика (сірий день). Олія; 69. Піонер за працею. Олія; 70-71; Пролетарські кутки. Олія; 72. Репях (будяки). Олія; 73. Селянський двір. Олія; 74. Сутінки. Олія; 74. Шатро. Олія. 1928. Перша виставка картин Полтавської філії АХЧУ. Полтава: 75. Алея. Олія; 76. Антиквар. Олія; 77-78. Будинок художньої галереї. Олія; 79. Весна. Олія; 80. Весняний мотив. Олія; 81. Вітряк. Олія; 82. Водяний млин. Олія; 83. Далечінь. Полтава. Олія; 84. Декоративне панно. Олія; 85. Декоративний мотив. Олія; 86. Зимовий день. Олія; 87. Намети. Олія; 88. Під весну. Олія; 89-90. Пролетарська частина. Полтава; 91-92. Пролетарські кутки. Олія; 93. Світанок. Олія; 94. Стіг. Олія; Перша пересувна художня виставка АХЧУ. Ізюм-Ахтирка-Суми-Богодухів: 95. Ввечері. Олія; 96. Робітничі околиці в Полтаві. Олія; 97. Сутеніє. Олія. - 1929. Виставка «Великий шлях» Дніпрельстан. Харків: 98. На Дніпрельстані. Панно. 1928; Друга виставка картин Полтавської філії АХЧУ. Полтава: 99. Грізний вечір; 100. Дівчина. Етюд; 101. Дніпровий мотив; 102. Етюд; 103. Зима; 104. Осінь; 105. Північ; 106. Після погрому (махновщина); 107. Портрет старого; 108. Сірий день; 109. Струмок. - 1930. Виставка «Культпохід на Донбас». Харків: 110. Воли. Олія; 111. Залізнична оселя. Олія; 112. Околиці м.Полтави. Олія; 113. Село Жуки на Полтавщині. Олія; 114. Сутінки. Олія. - 1930 1931. Третя всеукраїнська художня виставка НКО УРСР. Харків, Донбас, Запоріжжя, Дніпропетровськ, Київ, Одеса, Миколаїв: 115. Вихід комбайнів. Олія; 116. Після погрому. Олія. - 1935. Шоста українська художня виставка. Київ-Харків: 117. Зима. Олія; 118. Зимовий день. Олія; 119. Над Дніпром. Олія; 120. Натюрморт. Олія; 121. Осики. Олія. - 1936. Виставка «Мистецтво Радянської України». Харків: 122. Зимовий пей- 
заж. Олія; 123. Пейзаж. Олія. - 1937. Виставка етюдів України та Молдавії: Київ: 124. Південна частина Полтави. Олія; Ювілейна виставка творів художників УРСР» Київ: 125. Осики. Олія; 126. Передмістя Полтави. Олія; Юбилейная выставка произведений художников УССР. Москва: 126. - 1939. Друга осіння художня виставка. Харків: 127. Етюд. Олія; 128. Пейзаж. Полтава. Олія; 129. Яри. Олія. - 1940. Творча виставка художників м.Полтави та Полтавської області присвяченої ХХШ річниці Великої Жовтневої соціалістичної революції. Полтава: 130. Вестибюль музею. Олія; 131. Вечір. Олія; 132. Ворскла. Олія; 133. Вулиця в Полтаві. Олія; 134. Далечінь. Олія; 135. Дитбудинок в Уржумі, де виховувався т. Кіров. Олія; 136. Дніпрогес. Олія; 137. Домни в Макіївці. Олія; 138-139. Зима. Олія; 140. Зимовий ранок. Олія; 141. Картинна вулиця в Полтаві. Олія; 142. Молоді осики. Олія; 143. На каналі Волга-Москва. Олія; 144. Натюрморт «Жовті рози». Олія; 145. Натюрморт з скульптурою. Олія; 146. Натюрморт «Зів'ялі рози». Олія; 147. Околиці Полтави етюд. Олія; 148. П. О. Кириченко, стахановець колгоспу «Більшовик». Олія; 149. Подол. Олія; 150. Трактор. Олія. - 1941. Перша виставка творів художників міст: Дніпропетровська, Полтави, Прилук, Сталіно, Чернігова. Київ: 151. Зима. Олія (70 × 54,5); 152. Зима. Олія $(90,5 \times 120)$; 153. Зимовий ранок. Олія $(100 \times 80) ; 154$. Зів'ялі троянди. Олія $(55 \times 70)$; 155. Молоді осики. Олія $(90 \times 69) ; 156$. Околиці Полтави. Олія $(40 \times 76)$; 157. Поділ. Олія $(43 \times 63) ; 158$. Сутінки. Олія $(58 \times 137)$ (номери 151-158 власність Полтав. Худ .музею). Роботи в музеях: Дніпропетровськ. Художній музей: 1. Зимовий пейзаж. Олія $(100$ x 72). - Київ. державний музей українського мистецтва: 2. Весняний пейзаж. Олія (98 × 72); 3.Зимовий день. Олія $(81 \times 65,5) ; 4$. Полтава, південна сторона. Олія $(80$ x 200). - Полтава. Обласний художній музей: 5. Вулиця в Полтаві. Олія $(22$ × 14,5). 1939; 6. Околиці Полтави. Олія $(35$ × 25). 1941; 7. Просіка в лісі. Олія $(43$ × 60). 1939; 8. Ставок в с. Михайловському. Олія $(60 \times 79)$; 9. Троянди. Олія $(52 \times 65)$. 1937. Бібліографія та репродукції: Каталог виставки картин Полтавської філії АХРР'а. Полтава. 1926; «Глобус». К. 1927, № 16, ст. 252; Каталог першої всеукраїнської виставки художників Червоної України. Х. 1927 (з репрод.); Каталог першої виставки картин Полтавської філії АХЧУ. Полтава. 1928; Перша пересувна художня виставка АХЧУ. Ізюм-Ахтирка-Суми-Богодухов. Каталог. Х. 1928; Каталог другої виставки картин Полтавської філії АХЧУ. Полтава. 1929; газ. «Робітник Полтавщини». Полтава. 1929, 7. ХП, ч. 254; Культпохід на Донбас. Каталог. Х. 1930; Фіменський М. «Виставка «Великий шлях» Дніпрельстан». Каталог. Х. 1930 (з репрод.); «Червоний шлях». Х. 1930; № 9, ст. 115; Виставка «Мистецтво Радянської України». Каталог; Х. 1936; Ювілейна виставка творів художників УРСР. Каталог. Х. 1938; Юбилейная выставка произведений художников УССР. Х. 1938; Каталог другої осінньої художньої виставки. Х. 1939; газ. «Більшовик Полтавщини». Полтава. 1940, 3. XI; Каталог творчої виставки художників м. Полтави та Полтавської області присвяченої XXIII річниці Великої Жовтневої соціалістичної революції. Полтава. 1940 (з репрод.); Каталог. Перша виставка творів художників міст: Дніпропетровська, Полтави, Прилук, Сталіно, Чернігова. К. 1941 (з репрод.); «Образотворче мистецтво». К. 1941, № 2, (репрод.); газ. «Советская Украина». K. 1941, 11.VI.

Висновки 6 Таким чином, маємо надію, що запропоновані архівні матеріали та текст невеликої статті стануть підґрунтям для подальшого дослідження творчості майстра, що знайде своє втілення у написанні монографічної статті, складанні каталогу, альбому. 


\section{Список посилань}

Беседин, С.Ф. (1971, 20 апреля). Художник света и тепла (Фонд 1144 Дряпаченко Іван Кирилович - український художник - живописець, Опис 1, Справа 32). Центральний державний архів-музей літератури і мистецтва України, Київ.

Кондаков, С.Н. (1914). Юбилейный справочник Императорской Академии художеств, 1764 1914. Санкт-Петербург: Академия художеств.

Кудрицький, А.В. (Ред.). (1992). Розенбаум Соломон Аронович. В Митці України: Енциклопедичний довідник (с. 497-498). Київ: "Українська енциклопедія" ім. М.П. Бажана.

Курчакова, О., \& Бочарова, С. (2012). Іван Мясоєдов та його доба: Каталог виставки. Полтава.

Орлов, И.И. (б. г.). Воспоминания о художнике Соломоне Ароновиче Розенбауме. В Розенбаум Соломон Аронович: (Папка) (Фонд Підготовчі матеріали до неопублікованого словника "Художники Радянської України"). Архів відділу образотворчого та декоративно-прикладного мистецтва ІМФЕ ім. М.Т. Рильського НАН України, Київ.

Розенбаум Соломон Аронович: (Папка). (б. р.). (Фонд Підготовчі матеріали до неопублікованого словника "Художники Радянської України"). Архів відділу образотворчого та декоративно-прикладного мистецтва ІМФЕ ім. М.Т. Рильського НАН України, Київ.

Спарбер, М. (2001). Художник света и тепла (памяти Соломона Розенбаума). В В. Чазова, \& М. Спарбер. Чтобы помнили. Полтава: АСМИ. Взято из http://histpol.narod.ru/books/ memory/mem-021.htmm.

\section{References}

Besedin, S.F. (1971, April 20 ). Hudozhnik sveta i tepla [The artist of light and heat] (Fund 1144 Dryapachenko Ivan Kirilovich - ukraYinskiy hudozhnik - zhivopisets, Inventory 1, File 32). Central State Archive-Museum of Literature and Art of Ukraine, Kyiv [in Russian].

Kondakov, S.N. (1914). Yubileynyiy spravochnik Imperatorskoy Akademii hudozhestv, 1764 - 1914 [Anniversary Reference of the Imperial Academy of Arts, 1764-1914]. St. Petersburg: Academy of Arts [in Russian].

Kudrytskyi, A.V. (Ed.). (1992). Rozenbaum Solomon Aronovych. In Myttsi Ukrainy: Entsyklopedychnyi dovidnyk [Artists of Ukraine: Encyclopedic Directory] (pp. 497-498). Kyiv: "Ukrainska entsyklopediia" im. M.P. Bazhana [in Ukrainian].

Kurchakova, O., \& Bocharova, S. (2012). Ivan Miasoiedov ta yoho doba: Kataloh vystavky [Ivan Myasoyedov and his day: Exhibition catalog]. Poltava [in Ukrainian].

Orlov, I.I. (n. d.). Vospominaniya o hudozhnike Solomone Aronoviche Rozenbaume. In Rozenbaum Solomon Aronovich: (Folder) (Fund Pidhotovchi materialy do neopublikovanoho slovnyka "Khudozhnyky Radianskoi Ukrainy"). Archive of the department of fine arts and crafts of Institute of Art Studies, Folklore Studies and Ethnology. M.T. Rilsky NAS of Ukraine, Kyiv [in Russian].

Rozenbaum Solomon Aronovich: (Folder) (Fund Pidhotovchi materialy do neopublikovanoho slovnyka "Khudozhnyky Radianskoi Ukrainy"). Archive of the department of fine arts and crafts of Institute of Art Studies, Folklore Studies and Ethnology. M.T. Rilsky NAS of Ukraine, Kyiv [in Russian].

Sparber, M. (2001). Hudozhnik sveta i tepla (pamyati Solomona Rozenbauma) [The artist of light and heat (in memory of Solomon Rosenbaum)]. In V. Chazova, \& M. Sparber. Chtobyi pomnili [To remember]. Poltava: ASMI. Retrieved from http://histpol.narod.ru/books/memory/mem021.htmm [in Russian]. 